Published on Reviews in History (https://reviews.history.ac.uk)

\title{
INTERVIEW: Jordan Landes talks to Arthur Burns and Paul Readman
}

Review Number: 1989

Publish date: Thursday, 15 September, 2016

Editor: Chad Bryant

Arthur Burns

Paul Readman

ISBN: 9781137484970

Date of Publication: 2016

Price: $£ 65.00$

Pages: 332pp.

Publisher: Palgrave Macmillan

Publisher url: http://www.palgrave.com/us/book/9781137484970

Place of Publication: Basingstoke

Reviewer: Jordan Landes

In the latest of our occasional Reviews in History podcast series, Jordan Landes talks to Arthur Burns and Paul Readman about their new edited collection.

Arthur Burns is Professor of Modern British History at King's College London, UK. His books include Rethinking the Age of Reform: Britain 1780-1850 (2003), co-edited with Joanna Innes, and St Paul's: The Cathedral Church of London 604-2004 (2004), co-edited with Derek Keene and Andrew Saint.

Paul Readman is Professor of Modern British History at King's College London, UK. His publications include Land and Nation in England: Patriotism, National Identity and the Politics of Land 1880-1914 (2008), and as co-editor with Chad Bryant and Cynthia Radding, Borderlands in World History, 1700-1914 (2014).

Jordan Landes is history subject librarian at Senate House Library, University of London.

Listen to the interview here [2].

Source URL:https://reviews.history.ac.uk/review/1989

Links

[1] https://reviews.history.ac.uk/item/241399

[2] http://podcast.ulcc.ac.uk/accounts/SAScasts/ReviewsinHistory/JordanonRedmanandBurns.mp3 